\title{
ACTA NUMISMATICA HUNGARICA
}

2019

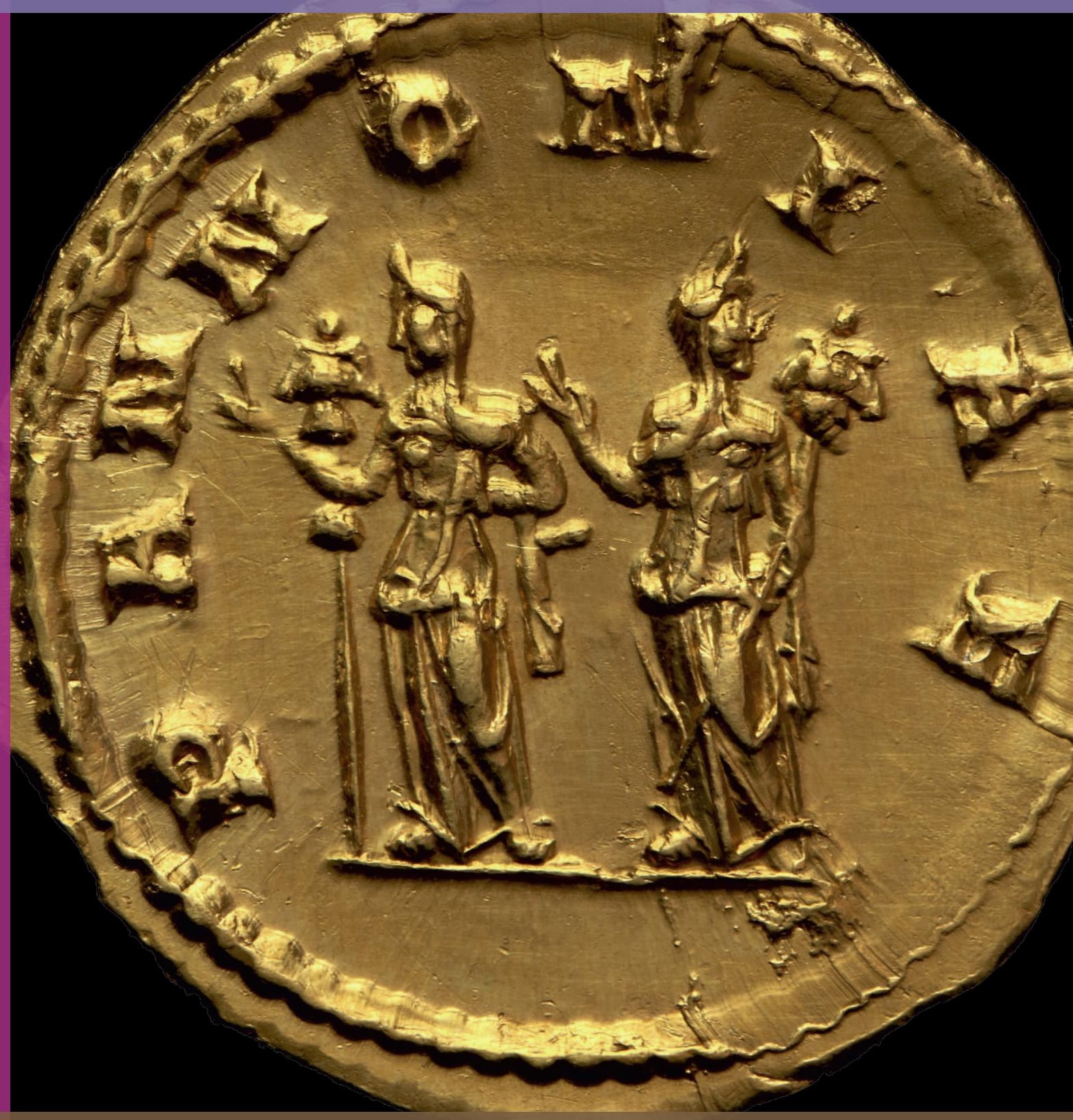

JOURNAL OF THE HUNGARIAN

NUMISMATIC SOCIETY 


\title{
ACTA NUMISMATICA HUNGARICA
}

\author{
I \\ Journal of the Hungarian \\ Numismatic Society
}

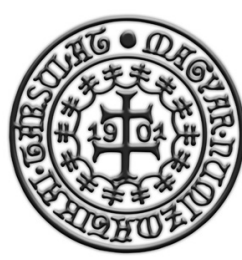

BUDAPEST 2019 


\title{
Acta Numismatica Hungarica
}

\author{
I \\ Editor-in-chief: \\ IsTVÁN VIDA \\ Editor: \\ LAJOS JuHÁsZ
}

Editorial board:

József Géza Kiss

Lajos Pallos

Gergely Sallay

FERENC Soós

Róbert UjSZÁsZI

Technical editor:

ENIKŐ KovÁcs

Contact: acta@numizmatika.org

Available online at http://acta.numizmatika.org

(c) Hungarian Numismatic Society

Cover design: Gábor Váczi

ISSN 2677-0598

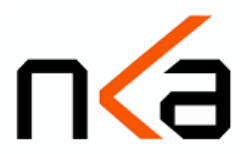

Budapest 2019 


\section{Contents}

Editorial foreword

Abbreviations of Journals and Periodicals 9

Katalin BíRÓNÉ SEY

Lajos Huszár (1906-1987)

Bibliography of Lajos Huszár

Melinda TORBÁGYI

A rare Celtic drachm 37

F. Péter Kovács - Melinda TorbágyI

Celtic coins from the Middle Tisza Region

(Jász-Nagykun-Szolnok County, East Hungary) 41

Lajos JuHÁsz

The Pannonian war of Aelius Caesar

and Antoninus Pius a fiction of modern scholars? 45

Tamás FeHÉr

A mysterious Gallienus bronze coin with SPES PVBLICA reverse 55

Alain GenNARI

The "Sirmium group": about the so-called Gepids siliquae.

With a specific catalogue -2 nd edition 63

István VIDA - Alain GENNARI

An imitative hexagram of the $7^{\text {th }}$ century 253 
Enikő KovÁcs

Medieval pattern coin from Esztergom

Enikő KovÁcs

Late medieval finds from Kisnémedi Church Hill 263

Lajos PAllos

The Numismatic Collection of the Hungarian National Museum

271

Reviews 307 


\title{
Lajos Huszár (1906-1987)
}

\author{
Katalin BíróNÉ SEY
}

He was an outstanding researcher and personality of 20th century numismatics. He had been working in the Coin Cabinet of the Hungarian National Museum for almost forty years (1929-1968), then in the collection of the Semmelweis Museum, Library and Archives of the History of Medicine until his death.

His life and work became closely intertwined with the Hungarian Numismatic Society, too, of which he had been a member since 1929. In 1941 he became an honorary member, then in 1985 an honorary president. From 1945 he was the executive vice-president of the Society, then from 1950 secretary of the merged Numismatic Section of the Numismatic Society and Archaeological Society. He held this position till 1968.

From 1933 to 1975 he was the editor of the only scientific numismatic journal, the Numizmatikai Közlöny. In the 1950s he was able to save the it from liquidation. Moreover, he was also able to find necessary resources for the journal, as the support provided by the Hungarian Academy of Sciences was very modest. The Society organised "coin exchange intermediation" (as the auctions had to be called then) and the few percent profit covered the costs of editing and printing the Numizmatikai Közlöny.

The career of Lajos Huszár was not smooth. In 1929 he volunteered as an intern in the Coin Cabinet and in 1944 he became department manager. He was a loyal employee of the museum. In 1944, when the siege of Budapest was approaching, the most precious items of the collections were buried in the cellar of the museum. Lajos Huszár was one of the few who knew the secret place.

The employees of the museum who survived the siege with minor injuries elected him Acting Director General in the spring of 1945, and the election was reinforced by the authorities later. From August 1946 till January 1949 he served as Appointed Director General of the museum. At the time he was suspended from the post of Director General for disciplinary reasons, on the pretext of the stolen Esterházy treasure and as a "punishment" he was downgraded to the status of an employee in the Coin Cabinet. There was a perfect excuse to remove him, because he could not be influenced politically, he was a hard-headed Szekler man, "góbé"; he was not among the beneficiaries of the system.

In 1955 he was department manager again. In 1956, during the revolution, he was member, then chairman of the provisional National Council of the museum. There was no consequence of this later in his career.

On 31 October 1968 he retired! He did not resign, he was sent to retirement, he did not leave the museum, the museum left him. The reason for his dismissal was unclear, linked to the gold of the Niklovits Collection, which was presumably taken out of the country during World War II. The suspicion has never been proven in written form.

In 1968 he was just 62 years old, in the middle of his active career, after collecting huge resources, which was about to be published and shared. Fortunately, Semmelweis Museum employed him and supported his publications. The sudden retirement must have been a shock 
for him, but, of course, he never mentioned it. He had hardly any private life, his life was numismatics. This is why his oeuvre was so vast.

His ever declining health conditions showed how stressful the lack of trust of the management of the museum was for him both physically and mentally. József Antall, director of the Semmelweis Museum (later Prime Minister of Hungary) had great merit in employing Huszár as advisor and with the help of his contacts in medicine he made it possible for him to get the right treatment in Kútvölgyi Hospital, where his health condition improved. But, of course, the quiet atmosphere of the Semmelweis Museum also helped him, where he was acknowledged and appreciated. (More detailed biographies are in the following journals: NK 86-87 (1987-1988), 3-4; FolArch 39 (1988), 7-9; Századok 122 (1988), 279-281).

His main focus was on Hungarian or related coins, monetary history, Transylvanian coins and Hungarian medals. His vast oeuvre consists of more than 500 books, studies and articles. (For full bibliography see NK 86-87 (1987-1988) 22-36). He wrote his dissertation in numismatics on the engravers of Körmöcbánya (Kremnitz). His articles, studies and books were continuously published since 1929. His systematic research can be traced in his theses, which he wrote for gaining the title of D.Sc. in 1983. Theses on the History of Hungarian Coinage and Medals. (NK 86-87 (1987-1988) 7-21). His lifework was honoured with the title by the Hungarian Academy of Sciences.

His monograph on Hungarian medals, "Die Medaillen- und Plakettenkunst in Ungarn", a catalogue of Hungarian medals was published in 1932 in collaboration with Béla Procopius. This clearly shows his systematic work, which was characteristic of his 58year career in the field of Hungarian monetary history, medals and Transylvanian coinage.

Numismatic bibliography in collaboration with Mária Fejér (Bibliographia Numismaticae Hungaricae. 1977, 321 p.) was published in 1977 as a result of compiling the data of numismatic literature. The enumeration of his major works does not mean ranking, while all his works have equal importance in their own right.

He also made research in Transylvanian coinage earlier, too, which resulted in such publications as "Bethlen Gábor pénzei" (Coinage of Gábor Bethlen) in 1945 and "Báthoriak pénzei" (Coins of the Báthoris) in 1961. The completion of this research is his work "Az erdélyi fejedelemség pénzverése" (Coinage of the Transylvanian Principality), which unfortunately- was published posthumously in 1995. It is characteristic of his strong will and hardworking personality that he made corrections in the manuscript of this work even in the final hours of his life lying on his hospital bed.

"Münzkatalog Ungarn von 1000 bis heute" (1979), "Corpus Nummorum Hungariae III/1 - Habsburg-házi királyok pénzei 1526-1657" (1975) and so on. There is no need to further list his stopgap works, as they are all listed in the bibliography, they all prove that the author knew Hungarian numismatics so well and left a vacuum which will be hard to fill.

The computerised, fast-paced world of the end of the 20th and the beginning of the $21^{\text {st }}$ centuries with their technical and technological novelties might not be able to present a numismatist who would use all the advantage of the above and create more than Lajos Huszár did.

In his long and successful career he earned acknowledgements several times both in Hungary and abroad. In 1941 he received Signum Laudis, in 1959 ministerial acknowledgement, in 1961 the Flóris Rómer Award of the Hungarian Archaeological and Art History Society, in 1976 the László Réthy Medal of the Hungarian Numismatic Society, in 1980 the István 
Weszprémi Medal of the Medical History Society and the Ferenc Széchényi Medal of the Hungarian Numismatic Collectors' Society. In 1981 he was awarded the first class of the Order of Merit. He was also awarded foreign honours. In the 1930s he became a corresponding member of the Austrian and the Czechoslovak Numismatic Societies. In 1970 he was elected an honorary member of the Austrian, in 1971 the Croatian Numismatic Societies. In 1979 the International Numismatic Commission elected him an honorary member.

His greatest recognition was the D.Sc. title by the Hungarian Academy of Sciences for his lifework. In 1984 he also got the title of university professor titular.

His publications are available for everybody. But what he did and how he worked in the Coin Cabinet of the Hungarian National Museum is known only for a few. He did a tremendous job there, too. He put the medal section in order, made an accurate inventory and kept precise administration. He reorganised the system of coin storage. He introduced a user-friendly mobile box system, which was a huge effort, as he rearranged 300000 coins and medals. He acquired the Niklovits Collection, consisting of 43000 coins and medals of excellent condition, rarities among them, Celtic coins and medals, too. If Huszár had not taken action right after Niklovits's death and had not sealed his apartment and made the Coin Cabinet take care of the collection, the unique collection would have been lost and spread. These are only a few examples of his career in the museum.

All that has been said refers to the outstanding researcher, the accurate and reliable staff member, whose morals were not changed by the political changes. He served the cause of the museum with the ethics and morals and integrity he was brought up with in his parental home in Transylvania. He was deliberate, sober-minded, by delaying things and through his "wait-andsee" policy he wanted to avoid the destructive initiatives - and many times he was successful. The cautiousness of the Transylvanian Szekler minority characterised him. It took me a long time to get to know him working side by side with him and to begin to know and like his peculiarities.

He was very reserved. His brief and concise comments always hit the nail on the head. At the dinner table he was a good entertainer, never carried away by passion and never raised his voice. He kept his integrity till his death. He set a good example with his attitude to life both professionally and privately. 